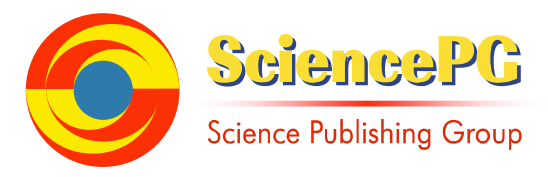

\title{
An Investigation into Factors Causing Delays in Road Construction Projects in Kenya
}

\author{
Msafiri Atibu Seboru \\ Department of Education and External Studies, University of Nairobi, Nairobi, Kenya \\ Email address: \\ mseboru@yahoo.com (Seboru, A. M.)
}

To cite this article:

Msafiri Atibu Seboru. An Investigation into Factors Causing Delays in Road Construction Projects in Kenya. American Journal of Civil Engineering. Vol. 3, No. 3, 2015, pp. 51-63. doi: 10.11648/j.ajce.20150303.11

\begin{abstract}
The majority of road construction projects in Kenya do not get completed within the initially set targets of time. Project delays frustrate the process of development, have an immeasurable cost implication to the society, and also lead to loss of reputation of the parties involved in the projects' execution. The purpose of this study was to investigate the factors causing delays in road construction projects in Kenya. Project delays are a common problem internationally in the construction industry in modern times. Investigating the reasons for delay has become an important contribution to improved construction industry performance. Over seventy percent of projects initiated in Kenya are likely to escalate in time with a magnitude of over fifty percent. The study used purposive sampling technique and survey design. Data was collected using questionnaires which were distributed to consultants and contractors. The data was analyzed using the Relative Importance Index and Spearman's rank correlation. The top five causes of project delays were observed to be payment by client, slow decision making and bureaucracy in client organization, inadequate planning and scheduling, and rain. It is recommended that clients should improve their financial management systems so that they are able to pay contractors in a timely manner. Bureaucracy and red tape should be reduced in client organizations in order to speed up the slow decision making process. Efficient management of the construction process will also lead to a reduction in incidences of claims. Contractors should prepare adequate plans and schedules which can also be used to minimize the effects of rain.
\end{abstract}

Keywords: Delay Factors, Project Delays, Road Construction Projects

\section{Introduction}

\subsection{Background of the Study}

Road construction projects in Kenya are procured through the traditional system where the Consultant Civil Engineer is in charge of design and construction processes on behalf of the Client. According to the traditional system, the design process ought to be completed prior to commencement of construction. The Client commissions the Consultant Civil Engineer who is briefed by the client. The Consultant Civil Engineer then develops the design and prepares contract documents. The tendering process begins by pre-qualifying contractors on the basis of experience, work capacity and past performance. The pre-qualified contractors are then invited to tender. The contract is normally awarded to the lowest bidder. The standard form of contract that is commonly used for civil engineering works in Kenya is FIDIC (International Federation of Consulting Engineers). The Consultant Civil
Engineer appoints a Resident Engineer to be permanently based on site to supervise the project. The Consultant Civil Engineer delegates some of his duties and powers under the contract to the Resident Engineer. The Resident Engineer holds monthly site meetings with the Contractor. The Consultant Civil Engineer and the Client usually attend these meetings. At the practical completion stage, an inspection is carried out and the project is handed over to the Client. The Contractor is expected to make good any defects within the Defects Liability Period that normally lasts for one year.

The study of causes of delay in road construction projects in Kenya was important because time is one of three pillars of construction project management: time, cost and quality. A study on project delays was expected to lead to a better understanding of the causes of inefficiency in road construction projects. Once the most important causes of significant delay causing factors are identified, the parties to the projects shall then be able to channel their energies and resources to the specific factors thereby reducing delays to the 
projects. The study on road construction is important in the Kenyan context because roads contribute to economic growth and poverty reduction.

The study was restricted to the construction phase of the project only, although it is acknowledged that decisions made in other stages prior to the commencement of construction phase do affect the construction process. As argued by Talukhaba (1999), the conditions prevailing during design can be controlled, because unlike construction, design occurs in an enclosed environment. For instance, it may not be easy to control rain in a construction site. Therefore, the greatest challenges in implementation of projects are likely to be experienced during the construction phase. The data collection was restricted to consulting engineering firms and contractors situated in Nairobi. Besides the majority of consulting engineering firms and contractors operating in Kenya are based in Nairobi. Therefore, the study was concerned with the delays observed during the construction process. The delays that occur during the design process are not part of this study. The following were the assumptions of the study as adapted from Talukhaba (1999): Firstly, there was homogeneity in the management of projects under study and therefore project management as a factor had a constant and equal impact on project delays since all the projects were implemented using the traditional procurement system; secondly, there were no differences in the traditional procurement system that could be attributed to the process such that projects implemented using the system had an equal chance of showing similar characteristics in performance; thirdly, the productivity of workers in the projects being studied was the same, hence variation in delays due to differences in worker productivity was negligible; fourthly, the output of the plant and equipment in the projects being studied was the same, hence variation in delays due to differences in machine output was negligible; and lastly, the project contract period the parties agreed to adhere to was adequate for the completion of the project, and therefore the delays observed by the projects in the sample were not as a result of contract time underestimation.

Fan and Kang (2005) assert that roads contribute to economic growth and poverty reduction. Road infrastructure impacts on overall economic growth, agricultural growth, urban growth, urban poverty reduction, and rural poverty reduction. Without infrastructure, efficient markets, adequate health care, a diversified rural economy, and sustainable economic growth will remain elusive. Effective development strategies require good infrastructure as their backbone. Transportation infrastructure is an effective factor of production. Power consumption and health conditions are positively correlated with the availability of road infrastructure. Most of Africa's poor trade performance is the result of weak infrastructure. The availability and quality of road infrastructure also influences food prices. Road investments help the poor through their impact on the rural non-farm economy. An increase in paved roads is positively and significantly related to growth in Gross Domestic Product (GDP) per capita in urban areas.

Fan and Kang (2005) continue to argue that the different phases of a highway project have different impacts. The construction period not only creates tremendous work opportunities, but also improves the skill of local people employed on the project. In the post-construction period, highways promote the development of goods production in poor regions, increase the volume of trade, reduce transportation costs, and improve social services. Highway construction also increases farm incomes.

Nadiri and Mamuneas (1998) argue that an increase in the stock of highway capital has an initial direct productivity effect on business: it reduces the total cost of producing a given level of output in almost all industries. Cost reductions permit products to be sold at lower prices and lower prices can be expected to lead to output growth. Road investments have a significant effect on the production sector's demand for labour, capital, and materials.

\subsection{Research Problem}

The majority of road construction projects in Kenya do not get completed within the initial set targets of time. Talukhaba (1999) argues that project delay frustrates the process of development, has an immeasurable cost to the society, and also leads to loss of reputation of the parties involved in the concerned projects. Mbatha (1986) and Talukhaba (1988) revealed that time performance of construction projects in Kenya was poor to the extent that over seventy percent of projects initiated in Kenya were likely to escalate in time with a magnitude of over fifty percent.

One of the most widely used measures of project success is time taken to complete the project. Talukhaba (1999) carried out research on factors causing construction project delays in Kenya based on a case study of high rise building projects in Nairobi but did not cover road construction projects. Road construction projects are more mechanised than building projects. Some of the materials used in road construction projects are different from the materials used in building projects. Activities in road projects are more exposed to the weather than activities in building projects. The Civil Engineer is largely the sole player in road projects with minimal involvement of other construction professionals as opposed to building projects where the various professionals play significant roles. Road projects are essentially public projects whereas building projects could either be public or private. It is therefore the purpose of this study to investigate the factors causing delays in road construction projects in Kenya.

\subsection{Objectives of the Study}

The objectives of this study were:

1. To document the range of identified causes of delay in completing road construction projects in Kenya;

2. To document the most important causes of delay in road construction projects in Kenya; and

3. To document identified differences in perception of contractors and consultants regarding causes of delay in delivering projects by the intended completion date. 


\subsection{Research Hypothesis}

Ho: Road construction project delays are not caused by exogenous and endogenous factors.

Ha: Road construction project delays are caused by exogenous and endogenous factors.

Exogenous factors are external factors to the project such as politician's interference, inflation and interest rates. Endogenous factors are internal factors in the project such as contractor's cash flow, design change by engineer, and inadequate planning/scheduling.

\subsection{Significance of the Study}

This work is important because time is one of three pillars of construction project management: time, cost and quality. A study on project delays will lead to a better understanding of the causes of inefficiency in road construction projects. Once the most significant delay causing factors are identified, the parties to the projects shall then be able to channel their energies and resources to the specific factors thereby reducing delays to the projects.

Walker (1994) carried out an investigation in Australia on construction time performance and concluded that through improving its productivity, the construction industry can have an important role in promoting national competitiveness, and therefore in defending living standards and achieving a satisfactory rate of growth. The benefits from such improvement would include increased attractiveness of Australia as a location for investment in new plants or projects. Measures that prevent or slow steps toward improving building and construction industry productivity are, in effect, an attack on the employment prospects and future welfare of Australian workers. Such measures would also be an attack on the potential performance of Australian industry and the economy generally.

The above view can also be applicable to Kenya and reinforces the argument for attention to construction time performance. The study on road construction is important in the Kenyan context because roads contribute to economic growth and poverty reduction.

\section{Literature Review}

Delays in construction projects are still very common in most parts of the world even with the introduction of modern management techniques. Studies conducted on the causes of construction project delays in 22 different countries of the world have been examined.

Talukhaba (1999) carried out an investigation into factors causing construction project delays in Kenya and found out that the major causes of delay were: Clients payment; Architect's instructions; Client's instructions; Rock; and Underground water. Assaf, Al-Khalil and Al-Hazmi (1995) studied the causes of delay in large building construction projects in Saudi Arabia and revealed that the most important causes of delay were: Approval of shop drawings; Delays in payments to contractors and the resulting cash-flow problems during construction; Design changes; Conflicts in work schedules of subcontractors; and Slow decision making and executive bureaucracy in the Owners' organisations. Mansfield, Ugwu and Doran (1994) studied the causes of delay and cost overruns in construction projects in Nigeria and the results showed that the most important factors were: Financing and payment for completed works; Poor contract management; Materials shortages; and Improper planning.

Al-Tabtabai (2002) conducted a study on causes of delays in construction projects in Kuwait and found out that the major causes of delay were: Slow financial and payment procedures; Slow decision-making process; Limited authority among supervision staff; Risk allocation mainly on the contractor; and Lack of design drawings coordination. Memon, Rahman and Azis (2012) conducted a study on time and cost performance in construction projects in Malaysia and revealed that only $21 \%$ of public sector projects and $33 \%$ of private sector projects were completed within time. The results of the study showed that the most important delay factors were: Design and Documentation Issues; Financial Resource Management; Project Management and Contract Administration; Contractors Site Management; and Information and Communication Technology.

Owolabi et al. (2014) studied the causes and effects of delay on project construction delivery time in Nigeria. They stated that seven out of ten projects in Nigeria suffered delays in their execution. The results of the study indicated that the following were the five major causes of delay: Lack of funds to finance the project to completion; Changes in drawings; Lack of effective communication among the parties involved; Lack of adequate information from consultants; and Slow decision making. In Ghana, Frimpong, Oluwoye and Crawford (2003) carried out a research on Causes of delay and cost overruns in construction of groundwater projects in developing countries. The researchers indicated that $75 \%$ of the projects in Ghana exceeded the original project schedule. The study revealed that the most important causes of delay were: Monthly payment difficulties; Poor contract management; Material procurement; Inflation; and Contractor's financial difficulties. In Morocco, Challal and Tkiouat (2012) researched on the causes of deadline slippage in construction projects and found out the five major causes of delay were: Errors in initial budget assessment; Architecture and engineering volatility program (multiple modification requests); Site hazards; Failure of an actor; and Insufficiency or lack of prior study and feasibility.

Alinaitwe, Apolot and Tindiwensi (2013) carried out a study on causes of delays and cost overruns in Uganda's public sector construction projects and the results showed the major causes as: Change of work scope and/or changes in material specifications; High inflation, insurance and interest rates; Poor monitoring and control, due to incompetent and/or unreliable supervisors; Delayed payment to contractors, subcontractors and/or suppliers; and Fuel shortages. Memon (2014) conducted a study on contractor perspective on time overrun factors in Malaysian construction projects and the major factors causing delays were: Frequent design changes; 
Change in the scope of the project; Financial difficulties of owner; Delays in decisions making; and Unforeseen ground conditions. In India, Desai and Bhatt (2013) studied the critical causes of delay in residential construction projects and found out that the most important delay factors were: Original contract duration was too short; Legal disputes between various parties; Ineffective delay penalties; Delay in progress payments by owner; and Delay to furnish and deliver the site to the contractor by the owner.

Sweis, Sweis, Hammad and Shboul (2008) studied delays in construction projects in Jordan and the major causes of delay were: Financial difficulties faced by the contractor; Too many change orders from owner; Poor planning and scheduling of the project by the contractor; Presence of unskilled labour; and Shortage of technical professionals in the contractor's organization. In India, Ravisankar, Anandakumar and Krishnamoorthy (2014) conducted a study on the quantification of delay factors in the construction industry. The researchers indicated that time overrun vary between $50 \%$ and $80 \%$ for projects completed worldwide. The study revealed that the most important causes of delay were: Shortage of unskilled and skilled labour; Design changes by owner or his agent during construction; Fluctuation of prices; High waiting time for availability of work teams; and Rework due to errors. Shanmugapriya and Subramanian (2013) investigated significant factors influencing time and cost overruns in Indian construction projects. The researchers indicated that $60 \%$ of projects in India suffered time overruns. The study found out that the following were the most significant factors causing time overruns: Material market rate; Contract modification; Rework of bad quality performance; Unclear specification; and Dependence on freshers to bear the whole responsibility.

Kholif, Hosny and Sanad (2013) analyzed time and cost overruns in educational building projects in Egypt and found out that the major causes of time overruns were: Political insecurity (instability); Financial difficulties of contractor; Escalation of material prices (inflation); High cost of skilled labour; and Difficulties in getting work permits from government. Kagiri and Wainaina (2008) studied time and cost overruns in power projects in Kenya and revealed that the major causes of time overruns were: Delayed payment to contractor; Employer cash flow problems; Delays in disbursement of funds by financiers; Bureaucracy of government agencies; and Delay of access to site. In Sri Lanka, Dolage and Rathnamali (2013) carried out a study causes of time overrun in construction phase of building projects and found out that the following were the major causes of time overrun: Delay in progress payment by clients; Inaccurate planning and scheduling of projects by contractors; Rainy weather; Non availability of experienced technical staff of contractor; and Excessive work in hand of the contractors. Sweis (2013) investigated factors affecting time overruns in public construction projects in Jordan and revealed that the major causes of delay were: Too many change orders from owner; Poor planning and scheduling of the project by the contractor; Ambiguities and mistakes in specifications and drawings; Slow decision making from owner; and Poor qualification of consultants, engineers and staff assigned to the project.

In South Africa, Baloyi and Bekker (2011) researched on causes of construction cost and time overruns and revealed that the following were the most important causes of time overruns: Incomplete drawings; Design changes; Clients' slow decision-making; Late issue of instructions; and Shortage of skilled labour. Alaghbari, Kadir and Salim (2007) studied the significant factors causing delay of building construction projects in Malaysia and found out that the major causes of delay were: Owners' financial difficulties and economic problems; Contractors' financial problems; Late supervision and slowness in making decisions; Consultants' slowness in giving instructions; and Lack of materials on market. Mohammed and Isah (2012) carried out a study on the causes of delay in Nigerian construction industry and the results showed that the major causes of delay were: Improper planning; Lack of effective communication; Design errors; Shortage of supply like steel, concrete; and Slow decision-making. Fugar and Agyakwah (2010) researched on delays in building construction projects in Ghana and found out that the most important causes of delay were: Delay in honouring payment certificates; Underestimation of cost of projects; Underestimation of complexity of projects; Difficulty in accessing bank credit; and Poor supervision. Kikwasi (2012) studied the causes and effects of delays and disruptions in construction projects in Tanzania and the results showed that the following were the major causes of delay: Design changes; Delays in payment to contractors; Information delays; Funding problems; and Poor project management.

Ibironke, Oladinrin, Adeniyi and Eboreime (2013) analysed the non-excusable delay factors influencing contractors' performance in Nigeria and revealed that the major delay factors were: Insufficient amount of equipment; Inaccurate time estimates; Monthly payment difficulties; Change orders; and Inaccurate cost estimates. Wong and Vimonsatit (2012) studied the factors affecting construction time in Australia and the results showed that the following were the major factors affecting construction time: Skills shortage, Financial difficulties; Shortage of labour; Unrealistic deadlines for project completion; and Unforeseen ground conditions. Hoai, Lee and Lee (2008) researched on delay and cost overruns in large construction projects in Vietnam and revealed that the most important causes of delay were: Poor site management and supervision; Poor project management assistance; Financial difficulties of owner; Financial difficulties of contractor; and Design changes.

Ayudhya (2011) evaluated the common delay causes of construction projects in Singapore and found out that the major causes of delay were: Delay in progress payment by owner; Adverse weather conditions; Main contractor financial problems; Evaluation of completed works; and Acts of God. Faridi and El-Sayegh (2006) studied the significant factors causing delay in the construction industry in the United Arab Emirates and revealed that the following were the most 
important factors causing delay: Preparation and approval of drawings; Inadequate early planning of the project; Slowness of the owner's decision-making process; Shortage of manpower; and Poor supervision and poor site management. Mahamid (2013) researched on the causes of time overrun causes in road construction projects in Palestine and found out that the major causes of time overrun were: Segmentation of the West Bank and limited movement between areas; Political situation; Progress payments delay by owner; Lack of efficient equipment; and Difficulties in financing project by contractor. In Malaysia, Abdulla, Rahman and Azis (2010) studied the causes of delay in Construction Projects and the results showed that the major causes of delay were: Cash flow and financial difficulties faced by Contractors; Contractor's poor site management; Ineffective planning and scheduling by Contractors; Inadequate Contractor experience; and Shortage of site workers.

El-Razek, Bassioni and Mobarak (2008) conducted a study on causes of delay in building construction projects in Egypt and found out that the most important causes of delay were: Financing by contractor during construction; Delays in contractor's payment by owner; Design changes by owner or his agent during construction; Partial payments during construction; and Non-utilization of professional construction/contractual management. Sambasivan and Soon (2007) researched on the causes and effects of delays in Malaysian construction industry and the results showed the following major causes of delay: Improper planning; Site management; Inadequate contractor experience; Finance and payments of completed work; and Subcontractors. Kamanga and Steyn (2013) studied the causes of delay in road construction projects in Malawi and revealed that the following were the major causes of delay: Shortage of fuel; Insufficient contractor cash flow / difficulties in financing projects; Shortage of foreign currency (importation of materials and equipment); Slow payment procedures adopted by client in making progress payments; and Insufficient equipment. Patil, Gupta, Desai and Sajane (2013) researched on the causes of delay in Indian transportation infrastructure projects and the results showed that the following were the most important causes of delay: Delay due to Land Acquisition; Environmental issues related with project; Financial closure; Change orders by the client; and Poor site management and supervision by Contractor.

Akogbe, Feng and Zhou (2013) studied delay factors for development construction projects in Benin and found out that the major causes of delay were: Contractor's financial capability; Owner's financial difficulties; Poor subcontractor performance; Materials procurement; and Changes in drawings. Mustapha (2013) researched on the factors of delays in project delivery in Ghana and found out that the major delay factors were: Delay in honouring payment certificates; Delay by sub-contractors; Fluctuation of prices; Difficulty in accessing bank credit; and Client initiated variations. Asiamah and Asiamah (2013) conducted a study on causes of delays in construction of public buildings in Ghana and revealed that the following were the most important causes of delay: Method of construction; Long bureaucratic process of honouring certificates; Variation orders; Cash flow problems; and Lackadaisical attitude to decision making. Andi, Lalitan and Loanata (2010) carried out a study on factors causing delays in structural and finishing works in Indonesia and the results showed that the following were the major causes of delay: Slow contractor's payment; Design changes during construction; Force Majeure; Bad weather; and Slow delivery of material. According to Kivaa (2000), one cause of poor time performance in construction projects in Kenya is the inadequacy of initial contract periods. These have been found to be inconsistently and erroneously calculated. The initial contract period is estimated using the estimator's personal intuition, which is based on his skill and past experience. The method does not consider, objectively and accurately, all the factors that influence the construction time of a project.

\section{Research Methodology}

The study dealt with road projects in Kenya but whose consultants and contractors were based in Nairobi. The population of road projects and the identity of the consultants and contractors involved in the projects were obtained from the records at the headquarters of Ministry of Roads and Public Works in Nairobi. A list of consulting engineering firms was obtained from the secretariat of the Association of Consulting Engineers of Kenya situated in Nairobi. The total number of Consulting Engineering firms that were approached was 15 whereas the number of Contractors was 16 . These were the firms that dealt with design and construction of roads and were based in Nairobi. Survey research design was used and questionnaires were delivered to participants in person to obtain primary data. Participants filled in the questionnaires in their own time without any assistance from the researcher. The questionnaires were collected from the participants after a period of about three weeks. This approach removed any undue pressure from the respondents and gave them the freedom to fill in the questionnaires as truthfully as possible.

The Likert rating scale was used in the questionnaire. An opportunity was left to the respondents to include and rate variables that might have been missed out. The variables in the questionnaire were adapted from the studies cited in the literature review. In total, 141 variables were identified. The 141 variables were grouped into 25 broad categories to facilitate objective analysis. The grouping considered variable relationships with each other as well as similarity in characteristics. For example, variables such as clay, rock, underground water and fossils were grouped together under the broad category of subsoil conditions. The variables identified were thus grouped under design problems, subsoil conditions, financial/economic problems, subcontractors problems, contractual disputes, permits/licences, weather conditions, labour availability, and site accidents. Other variables included politics, materials availability, proximity to required resources, equipment availability, shop drawings, site 
layout, industrial relations disputes, and sample of materials / work approvals. The rest of the variables included material testing, natural hazards, underground services, working environment, supervision / management staff availability, advanced technology, suppliers, and client problems.

The questionnaire was designed in such a way that the stratification of the data was easy for analysis. The questions involved recording the contribution of each variable to delay in the project on a rating scale of: 1 - Very Low; 2 - Low; 3 Slightly Low; 4 - Average; 5 - Slightly High; 6 - High; and 7 - Very High. The questions concentrated on past phenomena on the project. The interest was to show how the past events had affected the projects. The question that was asked in the questionnaire was "During the period of construction, what was the contribution of the given factors to delay in the project?".

According to Talukhaba (1999) researchers on construction projects have in many cases worked with relatively small sample sizes. For example, Nkado (1992) (as cited in Talukhaba, 1999) investigated information system for the building industry with a sample of 29 cases. Ogunlana, Promkuntong and Jearkjirm (1996) (as cited in Talukhaba, 1999) investigated the causes of delay in projects in Thailand basing their research on a sample of 12 projects. Uher (1996) (as cited in Talukhaba, 1999) investigated the cost estimating practices in Australia construction industry using a sample of 10 projects. The sample of 31 consultants and contractors used in this study is therefore well above what has been used in other studies in the construction industry elsewhere. On the other hand, the sample size determines the type of statistics to be applied. Therefore, by using a suitable statistical tool, some of the problems that could be associated with the sample size are minimised. The 31 cases in this study produced $61.3 \%$ positive response. Kothari (1990) indicates that the percentage of responses for survey-type research is as low as 20 to $30 \%$. Two methods were used to analyze the data: Relative Importance Index (RII) and Spearman's rank correlation. The data that was collected was presented in a tabular form. Analysis was then carried out on the data and the results were presented in a tabular form as well.

Kometa, Olomalaiye and Harris (1994) (as cited in Sambasivan \& Soon, 2007) used the relative importance index method to determine the relative importance of various causes of delays. The same method was adopted in this study. The seven-point scale ranged from 1 (very low) to 7 (very high) was adopted and transformed to Relative Importance Index (RII) for each factor as follows:

$$
\mathrm{RII}=\Sigma \mathrm{W} /(\mathrm{A} * \mathrm{~N})
$$

Where ' $\mathrm{W}$ ' is the weighting given to each factor by the respondents (ranging from 1 to 7); ' $A$ ' is the highest weight (7 in this case); and ' $\mathrm{N}$ ' is the total number of respondents. The $\mathrm{RII}$ value had a range from 0 to 1 ( 0 not inclusive). The higher the value of RII, the more important was the cause of delays.

Assaf and Al-Hejji (2006) (as cited in Kamanga \& Steyn, 2013) indicate that the Spearman's rank correlation is a relationship measure among different parties or factors and the strength and direction of the relationship. This study uses Spearman's rank correlation to show the level of agreement between two parties.

$$
\mathrm{rs}=1-6 \Sigma \mathrm{d}^{2} /\left(\mathrm{n}^{3}-\mathrm{n}\right)
$$

Where 'rs' is the Spearman's rank correlation coefficient; ' $d$ ' is the difference in ranking between any two parties; and ' $n$ ' is the number of factors. The correlation coefficient varies between +1 and -1 , where +1 implies a perfect positive relationship (agreement), while -1 results from a perfect negative relationship (disagreement). Sample estimates of correlation close to unity in magnitude imply good correlation, while values near zero indicate little or no correlation.

\section{Findings and Discussions}

The combined views for all delay factors for consultants and contractors are shown in Table 1. The overall top five causes of delay indentified by both consultants and contractors were: Payment by client $(\mathrm{RII}=0.759)$; Slow decision-making and bureaucracy in client organization $(\mathrm{RII}=0.699)$; Claims $(\mathrm{RII}=0.609)$; Inadequate planning / scheduling $(\mathrm{RII}=0.602)$; and Rain $(\mathrm{RII}=0.579)$. The ten most important views of the consultants are shown in Table 2. The top five causes of delay identified by consultants were: Payment by client (RII = 0.738); Slow decision-making and bureaucracy in client organization $(\mathrm{RII}=0.595)$; Inadequate planning / scheduling $(\mathrm{RII}=0.595)$; Different site conditions $(\mathrm{RII}=0.583)$; and Proximity to borrow pit $(0.571)$. The ten most important views of the contractors are shown in Table 3. The top five causes of delay identified by contractors were: Slow decision-making and bureaucracy in client organization $(\mathrm{RII}=0.755)$; Payment by client $(\mathrm{RII}=0.673)$; Engineer's certificates $(\mathrm{RII}=0.633)$; Claims (RII = 0.633); and Rain $(\mathrm{RII}=0.612)$. The Spearman's rank correlation coefficient between the consultants and contractors was calculated and found to be 0.64 which showed that there was a positive correlation between the views of consultants and contractors.

Payment by client is overall the most important cause of delay. According to consultants, payment by client is also the most important delay factor. However, according to contractors the most important cause of delay is slow decision-making and bureaucracy in client organization. Overall, the second most important delay factor is slow decision-making and bureaucracy in client organization. This delay factor also appears second in the view of consultants. However, in the view of contractors, the second most important cause of delay is payment by client. Overall, the third most important delay factor is claims. According to consultants the third most important delay factor is inadequate planning / scheduling. Contractors view Engineer's certificates as the third most important cause of delay. Inadequate planning / scheduling is overall the fourth most important cause of delay. According to consultants, the fourth most important delay factor is different site conditions. For contractors, the fourth most important delay factor is claims. Overall, the fifth most important factor is rain. This delay 
factor also appears fifth in the view of contractors. However, in the view of consultants, the fifth most important cause of delay is proximity to borrow pit. The findings of this research should be of importance to both local and international engineering and construction firms entering the road construction market in Kenya.

Delay Factors

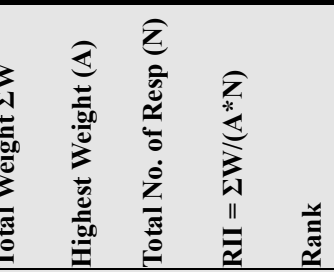

1. Design Problems

a) Conflicting design

information

b) Timeliness of revised

drawings issue

c) Missing information

d) Dimensional

inaccuracies

e) Design change by

Client

f) Design change by

Engineer

g) Different site

conditions

2. Subsoil Conditions

a) Clay

b) Rock

c) Underground water

d) Fossils

3. Financial/Economic

Problems

a) Payment by Client

$\begin{array}{lllllllllllllllllllllllll} & & & \end{array}$

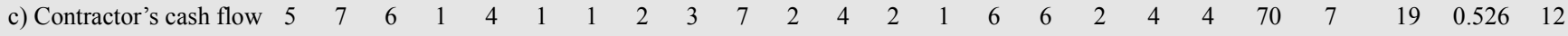

$\begin{array}{lllllllllllllllllllllllllllllll}\text { d) Interest Rates } & 2 & 6 & 1 & 1 & 5 & 5 & 1 & 2 & 6 & 5 & 2 & 1 & 1 & 1 & 1 & 6 & 2 & 5 & 3 & 58 & 7 & 19 & 0.436 & 31\end{array}$

$\begin{array}{lllllllllllllllllllllllllllll}\text { e) Inflation } & 2 & 3 & 1 & 1 & 5 & 5 & 1 & 2 & 5 & 5 & 4 & 3 & 1 & 4 & 2 & 3 & 2 & 5 & 5 & 63 & 7 & 19 & 0.474 & 26\end{array}$

f) Insolvencies and

bankruptcies

4. Subcontractors

Problems

a) Late nomination of

subcontractors

b) Poor workmanship

c) Labour problems

d) Material problems

e) Late payment

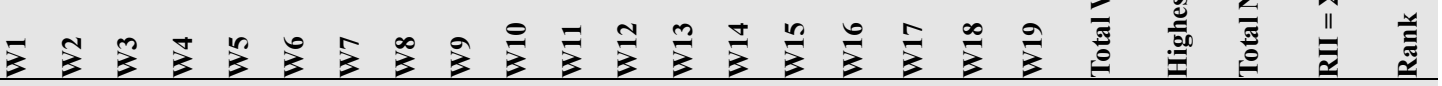

f) Relationship with main

contractor

g) Conflicts in work

schedules of

subcontractors

5. Contractual Issues

a) Poor workmanship

b) Variations

c) Claims

d) Inadequate

planning/scheduling

6. Permits/Licenses

$\begin{array}{llllllllllllllllllllllllllll}\text { a) Central Government } & 1 & 1 & 1 & 1 & 1 & 1 & 7 & 6 & 1 & 1 & 3 & 1 & 1 & 1 & 1 & 6 & 7 & 6 & 2 & 52 & 7 & 19 & 0.391 & 55\end{array}$

$\begin{array}{llllllllllllllllllllllllllllllllll}\text { b) Local Authority } & 3 & 5 & 1 & 1 & 3 & 1 & 7 & 7 & 2 & 1 & 4 & 1 & 1 & 1 & 1 & 6 & 7 & 7 & 2 & 65 & 7 & 19 & 0.489 & 21\end{array}$

c) Kenya Power \&

Lighting

d) Telkom Kenya

e) NEMA

$\begin{array}{llllllllllllllllllllll}4 & 3 & 1 & 1 & 5 & 4 & 1 & 6 & 3 & 3 & 2 & 1 & 1 & 1 & 1 & 7 & 2 & 7 & 1 & 56 & 7\end{array}$

$19 \quad 0.421 \quad 34$

7. Weather Conditions 
Delay Factors

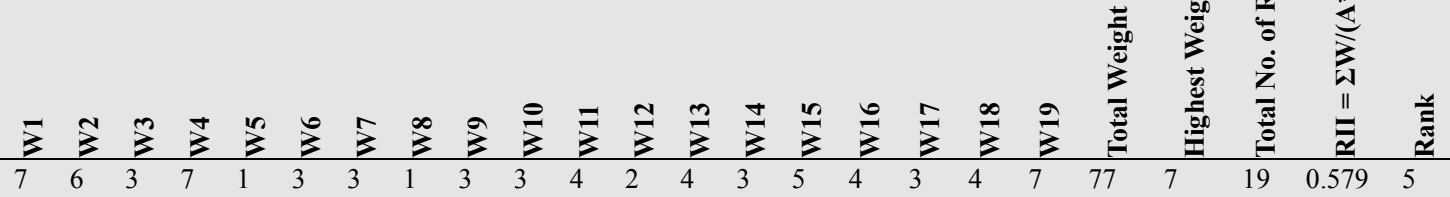

\begin{tabular}{llllllllllllllllllllllllll}
\hline a) Rain & 7 & 6 & 3 & 7 & 1 & 3 & 3 & 1 & 3 & 3 & 4 & 2 & 4 & 3 & 5 & 4 & 3 & 4 & 7 & 77 & 7 & 19 & 0.579 & 5 \\
b) Hot temperatures & 4 & 2 & 1 & 1 & 1 & 1 & 3 & 1 & 1 & 1 & 4 & 1 & 2 & 1 & 4 & 1 & 3 & 1 & 4 & 41 & 7 & 19 & 0.308 & 99 \\
c) Cold temperatures & 4 & 1 & 1 & 1 & 1 & 1 & 3 & 1 & 1 & 1 & 4 & 1 & 1 & 1 & 1 & 1 & 3 & 1 & 4 & 36 & 7 & 19 & 0.271 & 126
\end{tabular}

8. Labour Availability

a) Skilled

b) Unskilled

$\begin{array}{lllllllllllllllllllllllll}2 & 2 & 4 & 1 & 2 & 2 & 5 & 6 & 1 & 2 & 2 & 3 & 1 & 1 & 4 & 5 & 3 & 5 & 1 & 54 & 7 & 19 & 0.406 & 47\end{array}$

9. Site Accidents

a) Fatal

b) Serious injuries

c) Minor injuries

10. Politics

a) Politician's

interference

b) Political wrangling

between workers

$\begin{array}{llllllllllllllllllllllllll}\text { c) Political decrees } & 1 & 2 & 1 & 1 & 3 & 1 & 7 & 5 & 1 & 1 & 4 & 1 & 1 & 1 & 1 & 1 & 6 & 3 & 2 & 47 & 7 & 19 & 0.353 & 77\end{array}$

$\begin{array}{lllllllllllllllllllllllll}\text { d) Civil strife/riots } & 1 & 2 & 1 & 1 & 1 & 1 & 7 & 2 & 1 & 1 & 2 & 1 & 1 & 1 & 1 & 1 & 2 & 3 & 2 & 34 & 7 & 19 & 0.256 & 134\end{array}$

$\begin{array}{lllllllllllllllllllllllllllllll}\text { e) Protest action-groups } & 6 & 2 & 1 & 1 & 1 & 1 & 5 & 2 & 1 & 1 & 2 & 1 & 1 & 1 & 1 & 2 & 1 & 4 & 1 & 37 & 7 & 19 & 0.278 & 123\end{array}$

11. Materials Availability

a) Cement

b) Steel reinforcement

c) Timber

d) Sand

e) Aggregate

f) Bitumen

g) Murram

h) Water

i) Graded Crushed Stone

j) Hand packed stone

k) Lime

1) Structural steel

m) Explosives

n) Theft of materials

o) Wastage of materials

p) Double handling of

materials

q) Disposal of

construction waste

12. Proximity to

Required Resources

\begin{tabular}{|c|c|c|c|c|c|c|c|c|c|c|c|c|c|c|c|c|c|c|c|c|c|c|c|c|}
\hline a) Borrow pit & 7 & 3 & 1 & 4 & 6 & 5 & 7 & 5 & 1 & 4 & 4 & 1 & 2 & 1 & 1 & 5 & 6 & 4 & 3 & 74 & 7 & 19 & 0.556 & 8 \\
\hline b) Quarry & 6 & 4 & 1 & 1 & 6 & 5 & 7 & 5 & 1 & 4 & 4 & 2 & 2 & 1 & 1 & 5 & 7 & 4 & 4 & 74 & 7 & 19 & 0.556 & 8 \\
\hline c) Asphalt batching plant & 6 & 3 & 1 & 1 & 6 & 3 & 1 & 4 & 1 & 4 & 4 & 1 & 1 & 1 & 1 & 4 & 6 & 2 & 4 & 58 & 7 & 19 & 0.436 & 31 \\
\hline $\begin{array}{l}\text { 13. Equipment } \\
\text { Availability }\end{array}$ & & & & & & & & & & & & & & & & & & & & & & & & \\
\hline a) Crane & 1 & 2 & 1 & 1 & 6 & 1 & 7 & 3 & 1 & 3 & 4 & 1 & 1 & 1 & 4 & 3 & 1 & 4 & 3 & 52 & 7 & 19 & 0.391 & 55 \\
\hline b) Concrete mixer & 1 & 4 & 1 & 1 & 2 & 1 & 1 & 1 & 1 & 3 & 4 & 1 & 1 & 1 & 4 & 3 & 1 & 2 & 1 & 38 & 7 & 19 & 0.286 & 117 \\
\hline c) Excavator & 1 & 4 & 1 & 1 & 1 & 1 & 1 & 1 & 1 & 3 & 4 & 3 & 1 & 4 & 1 & 6 & 1 & 2 & 2 & 43 & 7 & 19 & 0.323 & 93 \\
\hline d) Concrete vibrator & 1 & 4 & 1 & 1 & 1 & 1 & 1 & 1 & 1 & 3 & 4 & 1 & 1 & 1 & 1 & 4 & 1 & 2 & 1 & 35 & 7 & 19 & 0.263 & 129 \\
\hline e) Crushing plant & 4 & 5 & 1 & 1 & 1 & 1 & 1 & 2 & 1 & 3 & 4 & 3 & 1 & 3 & 1 & 6 & 1 & 4 & 3 & 50 & 7 & 19 & 0.376 & 68 \\
\hline f) Asphalt Paver & 1 & 5 & 1 & 1 & 1 & 1 & 1 & 2 & 1 & 3 & 4 & 1 & 1 & 5 & 1 & 5 & 1 & 2 & 1 & 42 & 7 & 19 & 0.316 & 96 \\
\hline g) Roller & 5 & 6 & 4 & 1 & 1 & 1 & 1 & 1 & 1 & 3 & 4 & 3 & 1 & 3 & 1 & 5 & 1 & 2 & 1 & 49 & 7 & 19 & 0.368 & 71 \\
\hline h) Grader & 4 & 7 & 4 & 1 & 1 & 1 & 1 & 1 & 1 & 3 & 4 & 2 & 1 & 3 & 1 & 6 & 1 & 2 & 1 & 49 & 7 & 19 & 0.368 & 71 \\
\hline i) Bulldozer & 3 & 5 & 1 & 1 & 1 & 1 & 1 & 1 & 1 & 3 & 4 & 2 & 1 & 4 & 1 & 6 & 1 & 2 & 1 & 44 & 7 & 19 & 0.331 & 88 \\
\hline j) Wheel loader & 3 & 5 & 1 & 1 & 1 & 1 & 1 & 1 & 1 & 3 & 4 & 2 & 1 & 4 & 1 & 6 & 1 & 2 & 1 & 44 & 7 & 19 & 0.331 & 88 \\
\hline k) Dump Truck & 7 & 6 & 5 & 1 & 1 & 2 & 1 & 1 & 1 & 3 & 4 & 3 & 1 & 1 & 1 & 6 & 1 & 2 & 1 & 52 & 7 & 19 & 0.391 & 55 \\
\hline 1) Dumper & 1 & 3 & 1 & 1 & 1 & 1 & 1 & 1 & 1 & 3 & 4 & 3 & 1 & 3 & 1 & 6 & 1 & 2 & 1 & 40 & 7 & 19 & 0.301 & 105 \\
\hline m) Bowser & 5 & 6 & 1 & 1 & 1 & 2 & 1 & 1 & 1 & 3 & 4 & 2 & 1 & 2 & 1 & 4 & 1 & 2 & 1 & 44 & 7 & 19 & 0.331 & 88 \\
\hline n) Lorry & 4 & 5 & 1 & 1 & 1 & 1 & 1 & 1 & 1 & 3 & 4 & 4 & 1 & 1 & 1 & 5 & 1 & 2 & 2 & 44 & 7 & 19 & 0.331 & 88 \\
\hline o) Pick-up & 4 & 3 & 1 & 1 & 1 & 1 & 1 & 1 & 1 & 3 & 4 & 1 & 1 & 2 & 1 & 5 & 1 & 2 & 1 & 39 & 7 & 19 & 0.293 & 109 \\
\hline p) Low loader & 5 & 3 & 1 & 1 & 1 & 1 & 1 & 2 & 1 & 3 & 4 & 1 & 1 & 3 & 1 & 3 & 1 & 4 & 1 & 42 & 7 & 19 & 0.316 & 96 \\
\hline
\end{tabular}

$\begin{array}{lll}19 & 0.383 & 63\end{array}$

$\begin{array}{lll}19 & 0.391 & 55\end{array}$

$\begin{array}{lll}19 & 0.414 & 41\end{array}$

$\begin{array}{lll}19 & 0.361 & 75\end{array}$

$\begin{array}{lll}19 & 0.444 & 30\end{array}$

$\begin{array}{lll}19 & 0.504 & 16\end{array}$

$\begin{array}{lll}19 & 0.511 & 13\end{array}$

$\begin{array}{lll}19 & 0.406 & 47\end{array}$

$\begin{array}{lll}19 & 0.414 & 41\end{array}$

$\begin{array}{lll}19 & 0.383 & 63\end{array}$

$\begin{array}{lll}19 & 0.353 & 77\end{array}$

$\begin{array}{lll}19 & 0.383 & 63\end{array}$

$\begin{array}{lll}19 & 0.346 & 80\end{array}$

$\begin{array}{lll}19 & 0.398 & 54\end{array}$

$\begin{array}{lll}19 & 0.346 & 80\end{array}$

$\begin{array}{lll}19 & 0.391 & 55\end{array}$

$\begin{array}{lll}19 & 0.421 & 34\end{array}$ 
Delay Factors
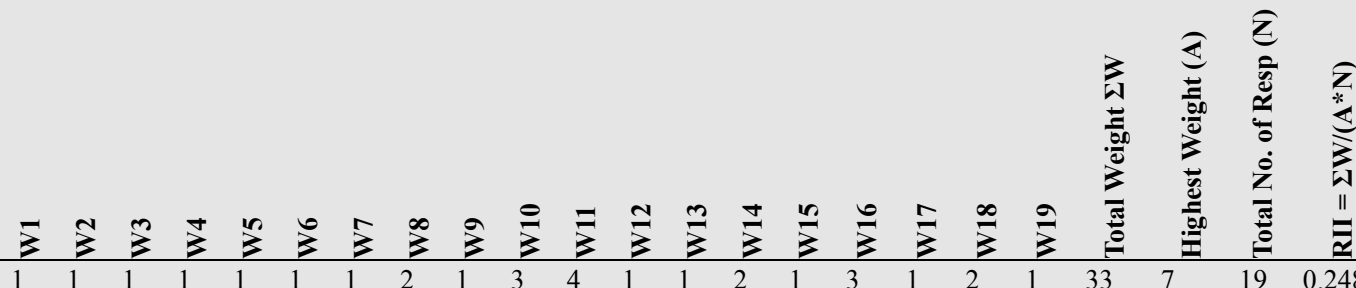

q) Conveyor

$\begin{array}{llll}1 & 1 & 1 & 2\end{array}$

r) Cement Silo

s) Compressor

t) Pump

u) Plate Compactor

$\begin{array}{llllllllllllllllll}1 & 1 & 1 & 1 & 1 & 1 & 1 & 2 & 1 & 3 & 4 & 1 & 1 & 1 & 1 & 1 & 1 & 2\end{array}$

$\begin{array}{lll}1 & 33 & 7 \\ 1 & 30 & 7 \\ 1 & 39 & 7\end{array}$

$19 \quad 0.226 \quad 138$

v) Chips Spreader

$\begin{array}{llllllllllllllllllllll}4 & 4 & 1 & 1 & 1 & 2 & 1 & 1 & 1 & 3 & 4 & 1 & 1 & 2 & 1 & 3 & 1 & 2 & 1 & 39 & 7\end{array}$

$19 \quad 0.293 \quad 109$

w) Theft of
machines/machine parts

14. Shop Drawings

a) Preparation

b) Approval

15. Site Layout

a) Access to site

entry/exit points

b) Congestion at site

entry/exit points

c) Storage space

16. Industrial Relations

Disputes

a) Wages

b) Safety

c) Welfare

d) Site communication

e) Labour camps

$\begin{array}{llllllllllllllllllll}1 & 3 & 1 & 1 & 1 & 1 & 1 & 2 & 1 & 3 & 4 & 1 & 1 & 2 & 1 & 3 & 1 & 2 & 1 & 35 \\ 4 & 3 & 1 & 1 & 1 & 1 & 1 & 2 & 1 & 3 & 4 & 3 & 1 & 5 & 1 & 4 & 1 & 3 & 1 & 45\end{array}$

$19 \quad 0.286 \quad 117$

$\begin{array}{lll}19 & 0.263 & 129\end{array}$

$\begin{array}{lllllllllllllllllllll}3 & 6 & 1 & 1 & 1 & 1 & 1 & 2 & 2 & 3 & 4 & 2 & 1 & 4 & 1 & 2 & 1 & 5 & 1 & 46\end{array}$

$190.338 \quad 84$

f) Discipline of workers

g) Absenteeism

17. Sample of

Materials/Work

Approvals

a) Client approval

b) Engineer approval

c) Re-work

18. Material Testing

a) Cement

b) Steel reinforcement

c) Timber

d) Sand

e) Aggregate

f) Bitumen

$\begin{array}{llllllll}1 & 2 & 1 & 1 & 6 & 5 & 5 & 6 \\ 1 & 2 & 1 & 1 & 5 & 5 & 5 & 5\end{array}$

$\begin{array}{ll}1 & 1 \\ 2 & 1\end{array}$

$\begin{array}{ll}6 & 1 \\ 5 & 1\end{array}$

$\begin{array}{lll}2 & 1 & 4 \\ 3 & 1 & 4\end{array}$

6
6

$\begin{array}{ll}3 & 64 \\ 4 & 65\end{array}$

$19 \quad 0.346 \quad 80$

$\begin{array}{llllllllllllllllllllll}1 & 2 & 1 & 1 & 3 & 4 & 1 & 2 & 3 & 1 & 4 & 1 & 2 & 1 & 4 & 2 & 2 & 4 & 2 & 45\end{array}$

$19 \quad 0.481 \quad 24$

$19 \quad 0.489 \quad 21$ 1

$\begin{array}{llllllll}1 & 2 & 1 & 1 & 3 & 4 & 1 & 2\end{array}$

1

$\begin{array}{ll}1 & 1 \\ 1 & 1\end{array}$

$\begin{array}{ll}4 & 1 \\ 4 & 1\end{array}$

11

$4 \quad 1$

21

432

$245 \quad 7$

$19 \quad 0.338 \quad 84$

g) Murram

h) Water

i) Graded Crushed Stone

j) Hand packed stone

k) Lime

1) Structural Steel

m) Asphalt

n) Soil

o) Rock

19. Natural Hazards

a) Fire

b) Floods

c) Landslides

d) Wind

20. Underground

Services

a) Electricity cables

$\begin{array}{llllllll}5 & 4 & 3 & 4 & 1 & 2 & 6 & 4\end{array}$

$\begin{array}{lllllllll}3 & 4 & 1 & 1 & 1 & 2 & 6 & 5 & 2\end{array}$

$\begin{array}{lllllllll}3 & 4 & 1 & 1 & 1 & 2 & 6 & 6 & 2 \\ 4 & 3 & 1 & 1 & 1 & 2 & 6 & 5 & 2\end{array}$

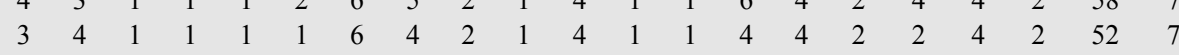

$19 \quad 0.338 \quad 84$

b) Telephone cables

c) Water pipes

d) Petroleum fuel pipes

e) Stormwater pipes

f) Data cables

$\begin{array}{llllll}1 & 2 & 1 & 1 & 1 & 1\end{array}$

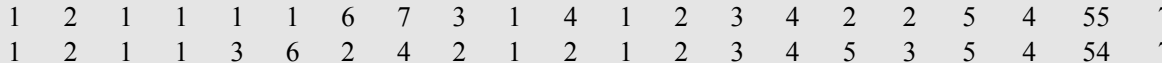

$\begin{array}{llllllllllllllllllllllll}3 & 2 & 1 & 4 & 5 & 3 & 4 & 3 & 3 & 4 & 4 & 2 & 2 & 4 & 1 & 2 & 3 & 4 & 2 & 60 & 7\end{array}$

$\begin{array}{lllllllllllllllllllll}1 & 2 & 1 & 1 & 1 & 1 & 2 & 5 & 1 & 1 & 2 & 2 & 3 & 1 & 1 & 2 & 2 & 5 & 2 & 38 & 7\end{array}$

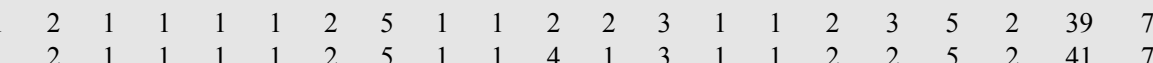
$\begin{array}{llllllllllllllllllll}2 & 2 & 1 & 1 & 1 & 1 & 2 & 5 & 1 & 1 & 2 & 1 & 3 & 2 & 1 & 1 & 2 & 5 & 2 & 38\end{array}$ $\begin{array}{lllllllllllllllllllll}2 & 2 & 1 & 1 & 1 & 1 & 2 & 5 & 1 & 1 & 2 & 2 & 3 & 2 & 1 & 2 & 2 & 5 & 2 & 40\end{array}$ $\begin{array}{lllllllllllllllllllll}6 & 2 & 1 & 1 & 2 & 1 & 2 & 5 & 1 & 1 & 2 & 1 & 4 & 2 & 1 & 2 & 2 & 5 & 2 & 45\end{array}$ $\begin{array}{lllllllllllllllllllll}7 & 2 & 1 & 1 & 4 & 1 & 2 & 5 & 1 & 1 & 2 & 2 & 2 & 3 & 1 & 3 & 2 & 5 & 2 & 49\end{array}$ 1 $\begin{array}{llllllllllllllllllll}2 & 1 & 1 & 1 & 1 & 2 & 5 & 1 & 1 & 2 & 1 & 1 & 1 & 1 & 1 & 2 & 5 & 2 & 34 & 7\end{array}$ $\begin{array}{llllllllllllllllllll}2 & 1 & 1 & 1 & 1 & 2 & 5 & 1 & 1 & 2 & 3 & 2 & 4 & 1 & 2 & 2 & 5 & 2 & 41 & 7\end{array}$ $\begin{array}{llllllllllllllllllll}1 & 2 & 1 & 1 & 4 & 1 & 2 & 5 & 1 & 1 & 2 & 1 & 2 & 1 & 1 & 2 & 2 & 5 & 2 & 39\end{array}$ $\begin{array}{llllllllllllllllllllll}1 & 2 & 1 & 1 & 1 & 1 & 2 & 5 & 1 & 1 & 2 & 1 & 3 & 1 & 1 & 2 & 3 & 5 & 2 & 38\end{array}$ $\begin{array}{llllllllllllllllllll}5 & 2 & 1 & 1 & 3 & 1 & 2 & 5 & 1 & 1 & 4 & 1 & 4 & 3 & 1 & 2 & 2 & 5 & 2 & 50\end{array}$ $\begin{array}{llllllllllllllllllll}1 & 2 & 1 & 1 & 3 & 1 & 2 & 5 & 1 & 1 & 2 & 1 & 2 & 1 & 1 & 3 & 2 & 5 & 2 & 39 \\ 1 & 2 & 1 & 1 & 2 & 1 & 2 & 5 & 1 & 1 & 2 & 1 & 2 & 1 & 1 & 3 & 2 & 5 & 2 & 38\end{array}$ $\begin{array}{lllllllllllllllllllll}1 & 1 & 1 & 1 & 1 & 1 & 1 & 2 & 1 & 1 & 2 & 1 & 1 & 1 & 1 & 2 & 2 & 4 & 1 & 28 & 7\end{array}$ $\begin{array}{llllllllllllllllllllll}2 & 3 & 3 & 7 & 1 & 1 & 6 & 2 & 3 & 1 & 4 & 1 & 1 & 1 & 1 & 2 & 5 & 5 & 3 & 56 & 7\end{array}$ $\begin{array}{lllllllllllllllllllll}2 & 2 & 1 & 4 & 1 & 1 & 1 & 2 & 1 & 1 & 3 & 1 & 1 & 1 & 1 & 1 & 3 & 4 & 2 & 36 & 7\end{array}$ $\begin{array}{llllllllllllllllllll}1 & 1 & 1 & 1 & 1 & 1 & 1 & 2 & 1 & 1 & 2 & 1 & 1 & 1 & 1 & 1 & 2 & 4 & 1 & 27\end{array}$

$\begin{array}{lll}19 & 0.414 & 41\end{array}$

$\begin{array}{lll}19 & 0.406 & 47\end{array}$

$19 \quad 0.451 \quad 28$

$\begin{array}{lll}19 & 0.286 & 117\end{array}$

$\begin{array}{lll}19 & 0.293 & 109\end{array}$

$\begin{array}{lll}19 & 0.308 & 99\end{array}$

$\begin{array}{lll}19 & 0.286 & 117\end{array}$

$\begin{array}{lll}19 & 0.301 & 105\end{array}$

$\begin{array}{lll}19 & 0.338 & 84\end{array}$

$\begin{array}{lll}19 & 0.368 & 71\end{array}$

$\begin{array}{lll}19 & 0.256 & 134\end{array}$

$\begin{array}{lll}19 & 0.308 & 99\end{array}$

$\begin{array}{lll}19 & 0.293 & 109\end{array}$

$\begin{array}{lll}19 & 0.263 & 129\end{array}$

$\begin{array}{lll}19 & 0.286 & 117\end{array}$

$\begin{array}{lll}19 & 0.376 & 68\end{array}$

$\begin{array}{lll}19 & 0.293 & 109\end{array}$

$\begin{array}{lll}19 & 0.286 & 117\end{array}$

$\begin{array}{lll}19 & 0.211 & 139\end{array}$

$\begin{array}{lll}19 & 0.421 & 34\end{array}$

$\begin{array}{lll}19 & 0.271 & 126\end{array}$

$19 \quad 0.203 \quad 140$

\begin{tabular}{lllllllllllllllllllllllll}
3 & 2 & 1 & 1 & 6 & 6 & 1 & 7 & 2 & 7 & 4 & 1 & 2 & 3 & 6 & 1 & 2 & 6 & 1 & 66 & 7 & 19 & 0.496 & 20 \\
3 & 2 & 1 & 1 & 6 & 6 & 1 & 7 & 2 & 7 & 4 & 1 & 1 & 2 & 6 & 1 & 5 & 6 & 1 & 67 & 7 & 19 & 0.504 & 16 \\
5 & 3 & 1 & 1 & 6 & 6 & 1 & 7 & 3 & 7 & 4 & 1 & 2 & 3 & 6 & 2 & 2 & 6 & 1 & 71 & 7 & 19 & 0.534 & 11 \\
1 & 1 & 1 & 1 & 6 & 1 & 1 & 2 & 1 & 2 & 4 & 1 & 1 & 1 & 1 & 1 & 2 & 6 & 1 & 39 & 7 & 19 & 0.293 & 109 \\
1 & 3 & 1 & 1 & 2 & 1 & 1 & 7 & 1 & 7 & 4 & 1 & 1 & 4 & 1 & 1 & 2 & 6 & 1 & 50 & 7 & 19 & 0.376 & 68 \\
1 & 1 & 1 & 1 & 1 & 1 & 1 & 7 & 1 & 7 & 4 & 1 & 1 & 1 & 6 & 1 & 1 & 6 & 1 & 48 & 7 & 19 & 0.361 & 75 \\
\hline
\end{tabular}




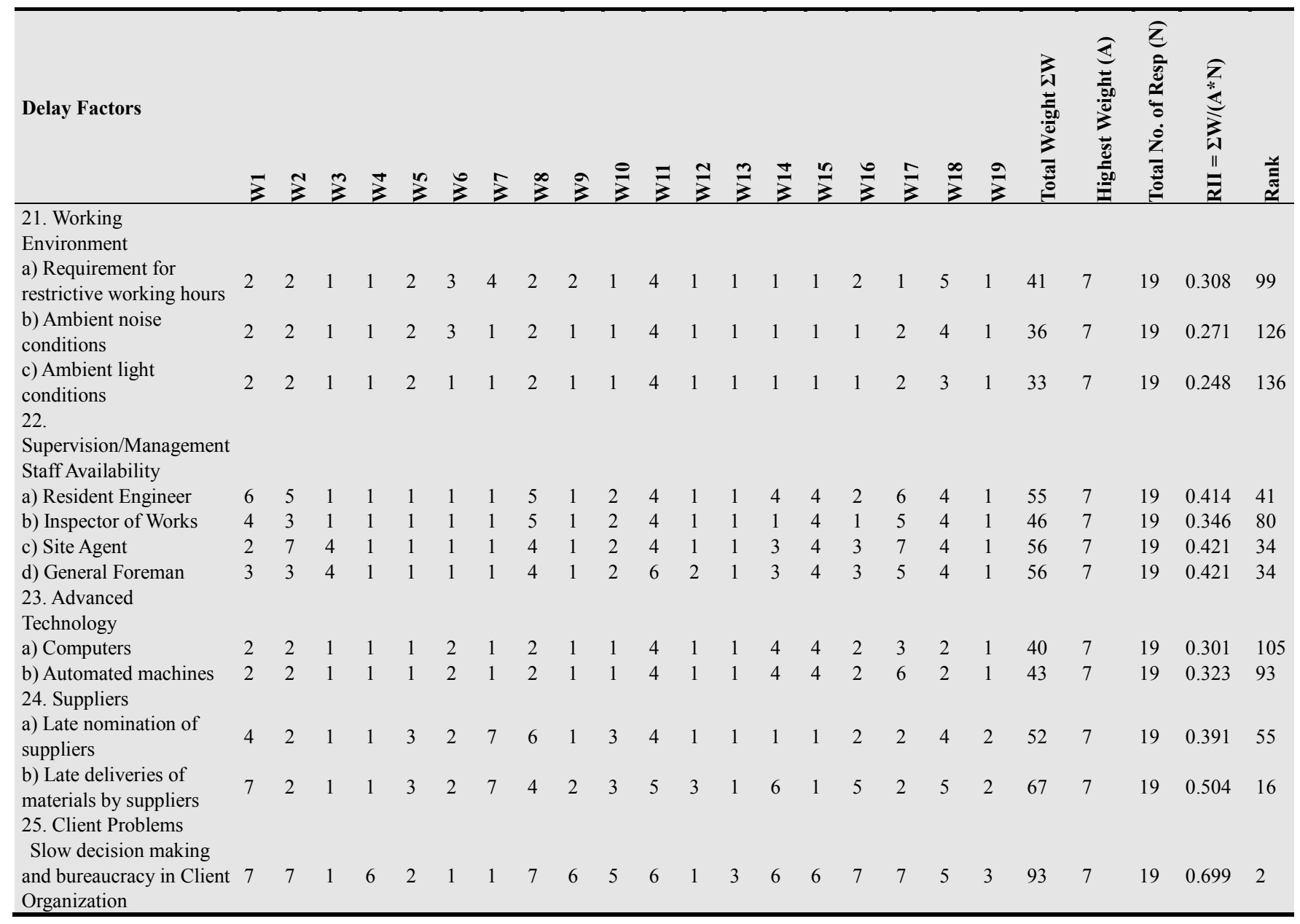

Table 2. Relative Importance Index and Ranking of Delay Factors for Consultants

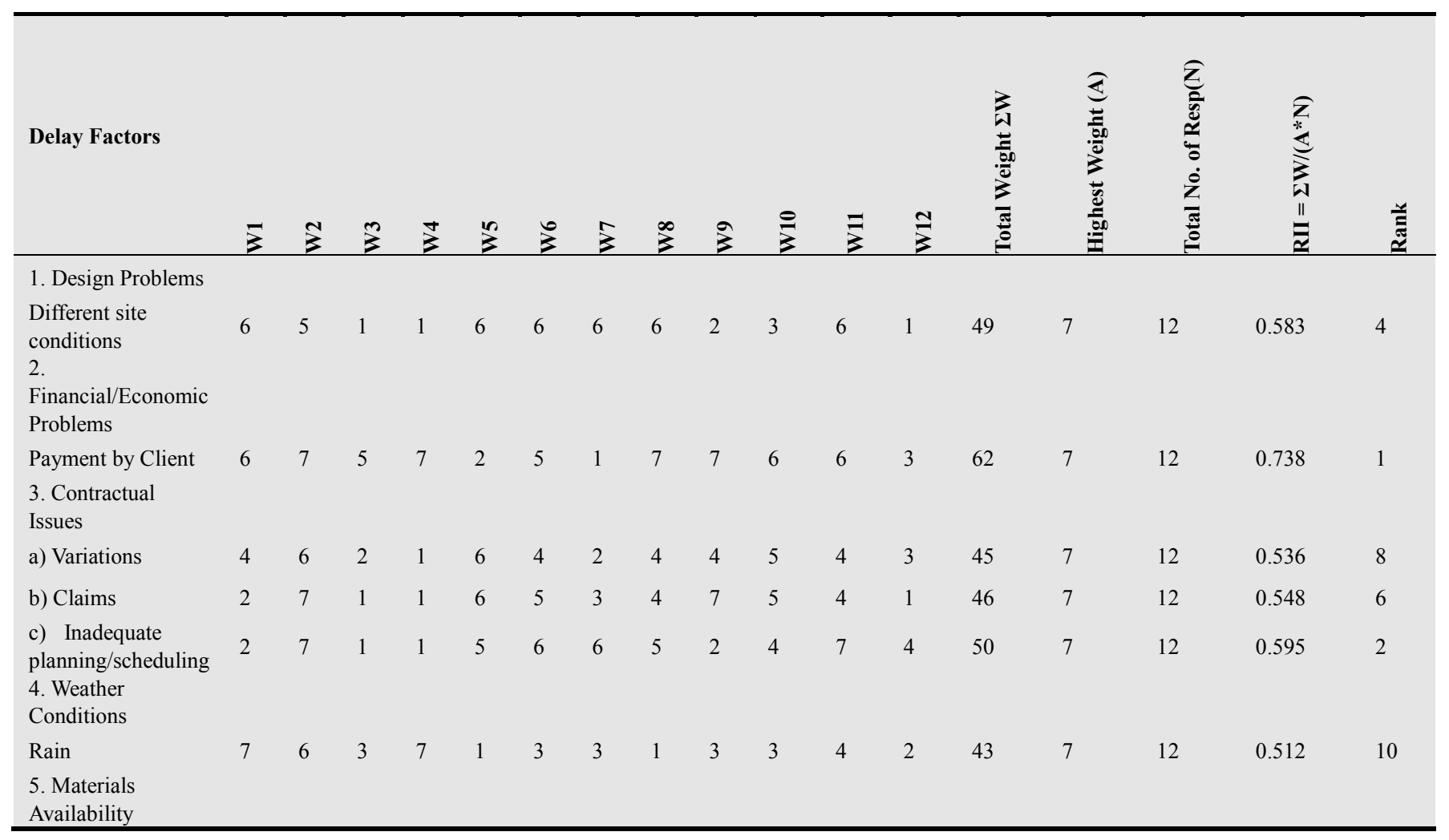




\begin{tabular}{|c|c|c|c|c|c|c|c|c|c|c|c|c|c|c|c|c|c|}
\hline $\begin{array}{l}\text { Murram } \\
\text { 6. Proximity to } \\
\text { Required Resources }\end{array}$ & 7 & 6 & 1 & 4 & 3 & 1 & 5 & 5 & 3 & 2 & 4 & 2 & 43 & 7 & 12 & 0.512 & 10 \\
\hline a) Borrow pit & 7 & 3 & 1 & 4 & 6 & 5 & 7 & 5 & 1 & 4 & 4 & 1 & 48 & 7 & 12 & 0.571 & 5 \\
\hline $\begin{array}{l}\text { b) Quarry } \\
\text { 7. Underground } \\
\text { Services }\end{array}$ & 6 & 4 & 1 & 1 & 6 & 5 & 7 & 5 & 1 & 4 & 4 & 2 & 46 & 7 & 12 & 0.548 & 6 \\
\hline $\begin{array}{l}\text { Water pipes } \\
\text { 8. Client Problems }\end{array}$ & 5 & 3 & 1 & 1 & 6 & 6 & 1 & 7 & 3 & 7 & 4 & 1 & 45 & 7 & 12 & 0.536 & 8 \\
\hline $\begin{array}{l}\text { Slow decision } \\
\text { making and } \\
\text { bureaucracy in } \\
\text { Client Organization }\end{array}$ & 7 & 7 & 1 & 6 & 2 & 1 & 1 & 7 & 6 & 5 & 6 & 1 & 50 & 7 & 12 & 0.595 & 2 \\
\hline
\end{tabular}

Table 3. Relative Importance Index and Ranking of Delay Factors for Contractors

\begin{tabular}{|c|c|c|c|c|c|c|c|c|c|c|c|c|}
\hline Delay Factors & $\sum^{2}$ & $\sum^{J}$ & $\stackrel{n}{2}$ & 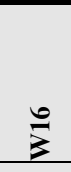 & 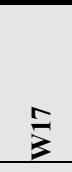 & $\sum^{\infty}$ & 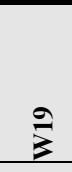 & 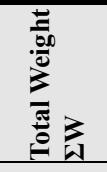 & 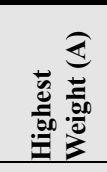 & 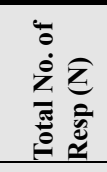 & 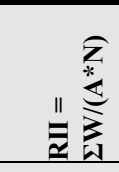 & 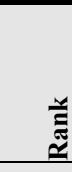 \\
\hline \multicolumn{13}{|l|}{ 1. Design Problems } \\
\hline a) Design change by Client & 3 & 5 & 1 & 2 & 7 & 1 & 7 & 26 & 7 & 7 & 0.531 & 7 \\
\hline \multicolumn{13}{|l|}{ 2. Financial/Economic Problems } \\
\hline a) Payment by Client & 2 & 1 & 4 & 7 & 7 & 7 & 5 & 33 & 7 & 7 & 0.673 & 2 \\
\hline b) Engineer's Certificates & 2 & 3 & 4 & 7 & 5 & 7 & 3 & 31 & 7 & 7 & 0.633 & 3 \\
\hline \multicolumn{13}{|l|}{ 3. Contractual Issues } \\
\hline a) Variations & 3 & 3 & 1 & 3 & 6 & 6 & 4 & 26 & 7 & 7 & 0.531 & 7 \\
\hline \multicolumn{12}{|l|}{ 4. Weather Conditions } & 3 \\
\hline $\begin{array}{l}\text { Rain } \\
\text { 5. Materials Availability }\end{array}$ & 4 & 3 & 5 & 4 & 3 & 4 & 7 & 30 & 7 & 7 & 0.612 & 5 \\
\hline \multicolumn{13}{|l|}{ 6. Shop Drawings } \\
\hline \multicolumn{13}{|l|}{$\begin{array}{l}\text { 7. Sample of Materials/Work } \\
\text { Approvals }\end{array}$} \\
\hline $\begin{array}{l}\text { Engineer approval } \\
\text { 8. Client Problems }\end{array}$ & 2 & 3 & 4 & 5 & 3 & 5 & 4 & 26 & 7 & 7 & 0.531 & 7 \\
\hline $\begin{array}{l}\text { Slow decision making and } \\
\text { bureaucracy in } \\
\text { Client Organization }\end{array}$ & 3 & 6 & 6 & 7 & 7 & 5 & 3 & 37 & 7 & 7 & 0.755 & 1 \\
\hline
\end{tabular}

\section{Conclusions and Recommendations}

This study was aimed at finding the causes of delay in road construction projects in Kenya. There were 141 causes of delay that were extracted from the literature on the subject. The 141 causes of delay were divided into 25 broad categories. The overall top five causes of delay indentified by both consultants and contractors were: Payment by client; Slow decision-making and bureaucracy in client organization; Claims; Inadequate planning / scheduling; and Rain. The
Spearman's rank correlation coefficient between the consultants and contractors was found to be 0.64 which showed that there was a positive correlation between the views of consultants and contractors. The range of causes of delay in completing road construction projects in Kenya was identified. The most important causes of delay in road construction projects in Kenya were also identified. The differences in perception of contractors and consultants regarding causes of delay in delivering projects by the intended completion date were identified as well. Therefore, the objectives of this study were substantially accomplished. 
The Null Hypothesis which states that road construction project delays are not caused by exogenous and endogenous factors is rejected. Hence the Alternative Hypothesis which states that road construction project delays are caused by exogenous and endogenous factors is accepted.

Clients should improve their financial management systems so that they could be able to pay contractors in a timely manner. Kamanga and Steyn (2013) suggest that while it is common practice for contracts to include a performance guarantee clause, there should also be a payment guarantee clause so that if a duly issued payment certificate is not paid by the client within the stipulated period, the contractor may demand his payment from the guarantor. Bureaucracy and red tape should be reduced in client organisations in order to speed up the slow decision making process. Claims should be settled quickly so that they do not become a source of delays. Contractors should prepare adequate plans and schedules during execution of road projects. During the rainy season, contractors should plan to execute activities that are not normally affected by the rain in order to mitigate delays.

The following are recommended areas for further research: Investigation of factors that cause delays in road projects during the design stage; Investigation of the impact of BOOT (Build Own Operate Transfer) method of procurement on construction time performance; Impact of usage of old equipment on road construction projects on construction time performance; and Impact of usage of concrete surfacing in lieu of asphalt on roads on construction time performance.

\section{References}

[1] Abdullah, M. R., Rahman, I. A., \& Azis, A. A. A. (2010). Causes of Delay in MARA Management Procurement Construction Projects. Journal of Surveying, Construction \& Property, 1(1), 123 - 138.

[2] Akogbe, R. T. M., Feng, X., \& Zhou, J. (2013). Importanceand Ranking Evaluation of Delay Factors for Development Construction Projects in Benin. KSCE Journal of Civil Engineering, 17(6), 1-10.

[3] Alaghbari, W., Kadir, M. R., \& Salim, A. (2007). The significant factors causing delay ofbuilding construction projects in Malaysia. Engineering Construction and Architectural Management Journal, 14(2), 192 - 206.

[4] Alinaitwe, H., Apolot R., \& Tindiwensi, D. (2013). Investigation into the Causes of Delays and Cost Overruns in Uganda's Public Sector Construction Projects. Journal of Construction a. in Developing Countries, 18(2), 33-47.

[5] Al-Tabtabai, H. M. (2002). Causes for Delays in Construction Projects in Kuwait. Engineering i. Journal of the University of Qatar, 15, 19- 37.

[6] Andi, A., Lalitan, D. \& Loanata, V. R., (2010). Owner and Contractor Perceptions Toward Factors Causing Delays in Structural and Finishing Works. Civil Engineering Dimension Journal, 12(1), 8 - 17Asiamah, A. D. A., \& Asiamah, O. K. A. (2013). Management of Government Funded Construction Projects in Ghana: Stakeholders' Perspective of Causes of Delays in Construction of Public Buildings. Journal of
International Institute for Science, Technologyand Education, 3(12) $149-156$.

[7] Assaf, S. A., \& Al-Hejji, S. (2006). Causes of Delay in Large Construction Projects. International Journal of Project Management, 24(4), 349 - $357 . \quad$ doi: 10.1016/j.ijproman.2005.11.010

[8] Assaf, S. A., Al-Khalil, M., \& Al-Hazmi, M. (1995). Causes of Delay in Large Building Construction Projects. Journal of Management in Engineering, 11(2), 45 - 50 Retrieved from

[9] Ayudhya, B. I. N. (2011). Evaluation of Common Delay Causes of Construction Projects in Singapore. Journal of Civil Engineering and Architecture, 5(11), 10271034

[10] Baloyi, L., \& Bekker, M. (2011). Causes of construction cost and time overruns: The 2010 FIFA World Cup stadiain South Africa. Acta Structilia, 18(10), 51 - 67.

[11] Challal, A., \& Tkiouat, M. (2012). Identification of the Causes of Deadline Slippage in Construction Projects: State of the Art and Application. Journal of Service Science and Management, $5,151-159$

[12] Desai, M., \& Bhatt, R. (2013). Critical Causes of Delay in Residential Construction Projects: Case Study of Central Gujarat Region of India. International Journalof Engineering Trends and Technology, 4(4), $762-768$.

[13] Dolage, D. A. R., \& Rathnamali, D. L. G. (2013). Causes of Time Overrun in Construction Phase of Building Projects: A Case Study on Department of Engineering Services of Sabaragamuwa Provincial Council. Engineer Journal of the Institution of Engineers of Sri Lanka. 46(03), 9 - 18. doi: 10.4038/engineer.v46i3.6780

[14] El-Razek, M. E. A., Bassioni, H. A., \& Mobarak, A. M. (2008). Causes of Delay in Building Construction Projects in Egypt. Journal of Construction Engineering and Management, 134(11), $831-841$.

[15] Fan, S., \& Kang, C. C. (2005). Road Development, Economic Growth, and Poverty Reduction in China, International Food Policy Research Institute Retrieved from http://www.ifpri.org/sites/default/files/publications/rr138.pdf

[16] Faridi, A. S., \& El-Sayegh, S. M. (2006). Significant Factors Causing Delay in the United Arab Emirates Construction Industry. Construction Management andEconomics Journal, 24(11), $1167-1176$.

[17] Frimpong, Y., Oluwoye, J., \& Crawford, L. (2003). Causes of delay and cost overruns in construction of groundwater projects in developing countries; Ghana as a case study. International Journal of Project Management, 21, 321326

[18] Fugar, F. D. K., \& Agyakwah, B. A. B. (2010). Delays in Building Construction Projects in Ghana, Australasian Journal of Construction Economics and Building, 10(1), 103 - 116.

[19] Hoai, L. L., Lee, Y. D., \& Lee, J. Y. (2008). Delay and Cost Overruns in Vietnam Large Construction Projects: A Comparison with Other Selected Countries. KSCE Journal of Civil Engineering, 12(6), 367 - 377.

[20] Ibironke, O. T., Oladinrin, T. O., Adeniyi, O., \& Eboreime, I. V. (2013). Analysis of Non- Excusable Delay Factors Influencing Contractors' Performance in Lagos State, Nigeria. Journal of Construction in Developing Countries, 18(1), 53 - 72. 
[21] Kagiri, D., \& Wainaina, G. (2008). Time And Cost Overruns in Power Projects in Kenya: A Case Study of Kenya Electricity Generating Company Limited. Paper presented at the $4^{\text {th }}$ International Operations Research Society of Eastern Africa (ORSEA) Conference.

[22] Kamanga, M. J., \& Steyn, W. (2013). Causes of Delay in Road Construction Projects in Malawi. Journal of The South African Institution of Civil Engineering, 55(3), $79-85$.

[23] Kholif, W., Hosny, H., \& Sanad, A. (2013). Analysis of Time and Cost Overruns in Educational Building Projects in Egypt. International Journal of Engineering and Technical Research, $1(10)$.

[24] Kikwasi, G. J. (2012). Causes and Effects of Delays and Disruptions in Construction Projects in Tanzania. Australasian Journal of Construction Economics and uilding, Conference Series, 1(2),52-59.

[25] Kivaa, P. T. (2000). Developing a Model for Estimating Construction Period: A Survey of Building Projects in Nairobi (Masters Thesis). University of Nairobi

[26] Kometa, S. T., Olomolaiye, P. O., \& Harris, F. C. (1994). Attributes of UK Construction Clients Influencing Project Consultants' Performance. Construction Management and Economics Journal, 12(5), 433 -443.

[27] Kothari, C. R. (1990). Research Methodology: Methods and Techniques, $2^{\text {nd }}$ Edition, New Delhi, New Age International (P) Ltd

[28] Mahamid, I. (2013). Frequency of Time Overrun Causes in Road Construction in Palestine: Contractors' View. Organization, Technology and Management in Construction Journal, 5(1), $720-729$

[29] Mansfield, N. R., Ugwu, O. O., \& Doran, T. (1994). Causes of Delay and Cost Overruns in Nigerian Construction Projects. International Journal of Project Management, 12(4), 254 260.

[30] Mbatha, C. M. (1986). Building Contract Performance: A Case Study of Government Projects in Kenya (Masters Thesis). University of Nairobi

[31] Memon, A. H. (2014). Contractor Perspective on Time Overrun Factors in Malaysian Construction Projects. International Journal of Science, Environment and Technology, 3(3), 1184 1192

[32] Memon, A. H. Rahman, I. A., \& Azis, A. A. A., (2012). Time and Cost Performance in Construction Projects in Southern and Central Regions of Peninsular Malaysia. International Journal of Advances in Applied Sciences, 1(1), 45 - 52.

[33] Mohammed, K. A. \& Isah, A. D., (2012). Causes of Delay in Nigerian Construction Industry. Interdisciplinary Journal of Contemporary Research in Business, 4(2) 785 - 794

[34] Mustapha, Z. (2013). Accelerated Factors of Delays on Project Delivery in Ghana: A Case Study of Cape Coast Metropolis. Journal of Applied Sciences \& Environmental Sustainability, $1(1), 54-61$.
[35] Nadiri, M. I., \& Mamuneas, T. P. (1998). Contribution of Highway Capital to Output and Productivity Growth in the U.S. Economy and Industries, United States Department of Transportation, Federal Highway Administration.

[36] Nkado, R. N. (1992). Construction Time Information System for the Building Industry. Construction Management and Economics Journal, 10(6), 489 - 509.

[37] Ogunlana, S. O., Promkuntong, K., \& Jearkjirm, V., (1996). Construction Delays in a fast-growing Economy: Comparing Thailand with other Economies.International Journal of Project Management, 14(1), 37-45

[38] Owolabi, J. D., Amusan, L. M., Oloke, C. O., Olusanya, O., Tunji, O. P., Owalabi, Omuh, I. (2014). Causes and effects of Delay on Project Construction Delivery Time. International Journal of Education and Research, 2(4), 197 - 208

[39] Patil, S. K., Gupta, A. K., Desai, D. B., \& Sajane, A. S. (2013). Causes of Delay in Indian Transportation Infrastructure Projects. International Journal of Research in Engineering and Technology, 02(11), 7180

[40] Ravisankar, K. L., Anandakumar, S., \& Krishnamoorthy, V. (2014). Study on the Quantification of Delay Factors in Construction Industry. International Journal of Emerging Technology and Advanced Engineering, 4(1), 105-113

[41] Sambasivan, M., \& Soon, Y. W. (2007). Causes and Effects of Delays in Malaysian Construction Industry.International Journal of Project Management, 25, 517 -526.

[42] Shanmugapriya, S., \& Subramanian, K. (2013). Investigation of Significant Factors Influencing Time and Cost Overruns in Indian Construction Projects. International Journal of Emerging Technology and Advanced Engineering, 3(10), $734-$ 740 .

[43] Sweis, G. J. (2013). Factors Affecting Time Overruns in Public Construction Projects: The Case of Jordan. International Journal of Business and Management, 8(23), 120 - 129.

[44] Sweis, G., Sweis, R., Hammad, A. A., \& Shboul, A. (2008). Delays in Construction Projects: The Case of Jordan. International Journal of Project Management, 26, 665674.

[45] Talukhaba, A. A. (1988). Time and Cost Performance of Construction Projects (Masters Thesis). University of Nairobi

[46] Talukhaba, A. A. (1999). An Investigation into Factors Causing Construction Project Delays in Kenya: A Case Study of High Rise Building Projects in Nairobi ( $\mathrm{PhD}$ Thesis). University of Nairobi

[47] Uher, T. E. (1996). Cost Estimating Practices in Australian Construction. Engineering, Construction and Architectural Management Journal, 3(1), 83 - 95.

[48] Walker, D. H. T., (1994), An Investigation into Factors that Determine Building Construction Time Performance $(\mathrm{PhD}$ Thesis). Royal Melbourne Institute of Technolog Australia.

[49] Wong, K., \& Vimonsatit, V. (2012). A Study of the Factors ffecting Construction Time in Western Australia. Scientific Research and Essays, 7(40), $3390-3398$. 